\title{
BANJARESE ISLAMIC SCHOLARS ('ULEMA) AND SOCIAL TRANSFORMATION IN TEMBILAHAN (PRELIMINARY RESEARCH) ${ }^{1}$
}

\author{
Raihani \\ Universitas Islam Negeri Sultan Syarif Kasim Riau, Indonesia \\ raihani@uin-suska.ac.id \\ Article history: \\ Submitted: 15-05-2018 | Revised: 30-10-2018 | Accepted: 15-11-2018
}

\begin{abstract}
Banjarese, an ethnic group in South Kalimantan, were estimated to have migrated to Tembilahan and its surroundings in the $19^{\text {th }}$ century following the defeat of the Banjar Sultanate by the Dutch colonialists. The religious intellectualism rooted in the Banjarese tradition has until now resulted in the production of 'ulema (religious scholars) even in new places to which they have migrated. Using in-depth interviews with several figures in Tembilahan, this preliminary study sheds light on how Banjarese 'ulema in the area have contributed to the transformation of society. This study is important as there has not been solid research-based information about this important topic publicly available. It found that Banjarese 'ulema have played an important role in educating people through formal and informal ways to be religiously committed and socio-economically active. They have demonstrated dynamic relations with society, but some of them were not immune from political and material temptations. It seems that the farther they stay away from such temptations, the more charisma they develop, and the more the opportunities they may have to contribute to the social transformation of Tembilahan society.
\end{abstract}

Keywords: Banjarese 'Ulema, Social Transformation, Indonesian Society

\begin{abstract}
Abstrak:
Urang Banjar, satu kelompok etnis di Kalimantan Selatan, diperkirakan bermigrasi ke Tembilahan dan sekitarnya pada abad ke-19 setelah Kesultanan Banjar dikalahkan oleh Belanda. Intelektualisme keagamaan yang mengakar dalam tradisi Urang Banjar sampai sekarang menghasilkan banyak ulama bahkan di tempat-tempat baru ke mana mereka bermigrasi. Menggunakan metode wawancara mendalam dengan beberapa tokoh di Tembilahan, studi pendahuluan ini memberikan pencerahan tentang bagaimana ulama Banjar di daerah ini berkontribusi terhadap transformasi social. Studi ini penting karena belum ada informasi yang solid dan berbasis riset tentang topik penting ini. Dari penelitian ini diketahui bahwa ulama Banjar memainkan peran yang penting dalam mendidik masyarakat melalui cara-cara formal dan informal agar menjadi warga yang secara keagamaan mempunyai komitmen dan
\end{abstract}

${ }^{1}$ The first version of this paper was presented at the International Conference on Social Transformation and Contemporary Banjarese held by IAIN Antasari Banjarmasin on August the 11th 2016. 
secara sosial dan ekonomi berperan aktif. Para ulama ini menunjukkan hubungan dinamis dengan masyarakat, walaupun di antara mereka tidak kebal terhadap godaan-godaan politik dan materi. Nampaknya, dari penelitian ini, semakin jauh mereka dari godaan tersebut, semakin besar karisma yang mereka bangun, dan semakin besar kesempatan yang mereka peroleh untuk berkontribusi terhadap transformasi sosial pada masyarakat Tembilahan.

\section{Kata Kunci: Ulama Banjar, Transformasi Sosial, Masyarakat Indonesia}

\section{Introduction}

'Ulema or religious scholars or intellectuals are a group of community elites who possess knowledge authority and exercise influence in changing society in terms of way of thinking, cultural and social aspects. In Gramsci's (18911937) categorisation, religious scholars are put in a group of ecclesiastic intellectuals who serve as a symbol of the continuity of history playing never-ending religious roles even in complex and radical changes of politics and society ${ }^{2}$.This elite group remains to exist forever to continue their religious functionary missions ${ }^{3}$. In Islam, 'ulema are considered as the heirs of the prophets who continuously deliver divine messages in order to develop a believing and contributing community.

Alatas ${ }^{4}$ divides the types of "ulema or intellectuals into functioning and non-functioning. He identifies capacities and skills of problem solving and social contribution as criteria of functioning intellectuals. In line with this, Edwards Said ${ }^{5}$ as cited in Taib $^{6}$ develops several characteristics of true intellectuals or scholars. First, $a$ sense of exile means that they put themselves ex-

\footnotetext{
${ }^{2}$ Antonio Gramsci, Prison Notebooks -- the Intellectuals: the Formation of the Intellectuals. In Roger S Gottlieb (Ed.). An Anthology of Western Marxism (New York: Oxford University Press, 1989), 113-120.

${ }^{3}$ Hiroko Horikoshi, A Traditional Leader in A Time of Change: The Kijaji and Ulama in West Java (Ph.D Unpublished) (The University of Illinois, Urbana-Champaign, 1976), 2.

${ }^{4}$ Syed Hussain Alatas, Intellectuals in Developing Societies (London: Frank Cass, 1977), 15.

${ }^{5}$ Edward Said, Representations of the Intellectual. (London: Vintage, 1994), 39.

${ }^{6}$ Mohammad Imron Mohammad Taib, Who is an Intellectual? 2017, 1-2. http://www.thereadinggroup.sg/Articles/Who\%20is\% 20an\%20Intellectual.pdf
}

iled from power especially political power. Said says that intellectuals must "stand as a marginal figure outside the comfort of privilege, power, and being-at-homeness"7. Second, speaking truth to power is a firm and brave attitude by intellectuals or scholars in holding up the truth and conveying it to the ruler. Third, amateurship means that they stay away from asking material rewards from people for their works and contributions. In defining amateurship, Said says: "[it is] the desire to be moved not by profit or reward but by love for and unquenchable interest in the larger picture [...]"8. In short, Said argues that intellectuals or scholars should demonstrate independency from being co-optated by any parties in their works as community elites to whom hopes and expectations are put by society. They are supposed to exercise influence on changing society and community.

Social changes are influenced by 'ulema who normally exercise through knowledge transmissions or education. Through education, 'ulema strive to change way of thinking and way of life of people, which in turn drive social changes and transformation. This relationship sounds, indeed, positive and optimistic ${ }^{9}$, contrasting many cases where education often function as preserving the established social norms and patterns. This means that, in contrast to its transformative function, education can play a significant role in reproducing inequality and injustice in soci-

\footnotetext{
${ }^{7}$ Edward Said, 43.

${ }^{8}$ Ibid., 57.

${ }^{9}$ Richard Desjardins, "Education and Social Transformation," European Journal of Education 50, no.3 (2015): 240.
} 
ety $^{10}$. This is to say, however education plays its role, it has significant influence on society, and 'ulema is one of the key players in this process of changes.

On the contrary, as indicated above by Said, 'ulema or intellectuals may also be influenced by changes or forces be they social, cultural or politics. This influence is made possible by the fact that they interact with society intensively and many of them believe that Islam as a religion should encompass all aspects of life or käffah. In the political realm, the interaction between Islam and politics has been contested and dynamic. "Islam and politics are like two sides of the same coin: Islam is the ideal and politics is the means to implement or realize that ideal in the life of the society"11. On some occasions, "ulema can become guardians of politics, but on other occasions they are not immune to political influences which can weaken their independence and undermine their integrity. This can be understood in the context of dynamic relations between religion and politics which in many cases religion is exploited for the gain of power ${ }^{12}$.

This paper tries to understand the roles of Banjarese 'ulema in Tembilahan in contributing to social transformation. Operationally defined, 'ulema means a group of elites in Banjarese community who are perceived by the community members as having the capacity in Islamic knowledge and actively interacting with society in order to spread Islamic teachings. The focus of this paper is on the dynamic changes of the roles of Banjarese 'ulema over time in exercising influences on social changes. I argue that besides the changes of knowledge capacity of contemporary 'ulema, social and political situations play an important role in shaping their roles in society.

\footnotetext{
${ }^{10}$ Pierre Bourdieu \& Jean-Claude Passeron, Reproduction in Education, Society and Culture, 2nd ed. (London: Sage, 1990), 7-9.

${ }^{11}$ Endang Turmudi, "Religion and Politics: A Study on Political Attitudes of Devout Muslims and the Role of the Kyai in Contemporary Java." Southeast Asian Journal of Social Science 23, no. 2. (1995): 20.

${ }^{12}$ Masdar Hilmy, “Agama dan Politik,” Kompas. 16 July 2014, 1.
}

\section{Research Methods}

This paper is generated from a preliminary study using interviews with several community figures in Tembilahan who I believe have the authority to speak about this important issue. They include figures from Banjar, Bugis and Malay. I used a snowballing strategy to select relevant informants. The findings this paper is reporting are based on preliminary investigation which means the depth of exploration and analysis is lacking. However, this can be an impetus for a larger study in or around this topic. Also, this research is perspectival which does not use first-hand data through observation as this can be categorised into an expos-facto exploratory research ${ }^{13}$.

Besides using interviews to collect data, I used secondary information such as books and research reports on the history of Banjarese people in Tembilahan and religious figures. The objective of doing this is to enrich the date being collected because not all informants speak accurately about historical facts. Therefore, information from previous research became very important in this research.

In analysing the data, I transcribed all the recordings in a selective way - focusing on information relevant to the objectives of this research. I coded and categorised both interview and archival data in order to generate patterns of themes. The emerging themes were then classified to ease the interpretation process. The interpretation process takes contextual information into account so that thick description can be enhanced in the report ${ }^{14}$.

\section{Madam (Migration) to Tembilahan}

In 'Becoming Banjar', Mary Hawkins ${ }^{15}$ explains that ethnographic studies on Banjarese

\footnotetext{
${ }^{13}$ Yvonna S. Lincoln and Egon G. Guba, Naturalistic Inquiry (Newbury Park: Sage Publications. 1985), 35; John W. Creswell, Research Design: Qualitative, Quantitative, and Mixed Methods Approaches (Los Angeles: SAGE Publications. 2009), 173-175. ${ }^{14}$ Matthew B. Miles and A. Michael Huberman, Qualitative Data Analysis (Thousands Oaks: SAGE Publications. 1994), 50-88.

${ }^{15}$ Mary Hawkins, "Becoming Banjar," Asia Pacific Journal of Anthropology 1, no.1 (2000): 25.
} 
community are still under researched compared to those on Borneo's Dayak. Researchers' interest on Dayak, according to Hawkins, is more because of romantic relationships between anthropologists with Borneo, not Kalimantan, who see primitive characteristics and exoticism of Dayak as unique. In fact, in marginalising studies about "coastal Malay", including Banjar experts have unconsciously formed an understanding that Banjar has its own unique characteristics and is equally important and interesting to study.

Becoming a Banjarese in Kalimantan, according Daud ${ }^{16}$ and Hawkins ${ }^{17}$, is identical as becoming a Muslim. The tie between Banjarese ethnic and Islam goes back to the history of Islamisation of this ethnic group in Kalimantan in the early $16^{\text {th }}$ century in a newly established city named Banjarmasin, now is the capital city of South Kalimantan. To distinguish themselves from non-Muslims and pledge an allegiance to the new sultanate, they named themselves people of Banjar. Since then, Islam has played an important role in this new community and they aspired to practice its teachings in all aspects of life, even though the influence of their previous religion, i.e. Hinduism and traditional beliefs has remained existence in daily life. However, the term "Banjar" to refer to both a certain place in Kalimantan and the religion of Islam started to be used when the awareness of becoming of citizens of Indonesia as a nation-state had developed among these people, especially when the Indonesian government emphasised on the importance of ethnicity as an identity in the governance or administrative system of the country where an ethnicity has to be mentioned as one of the formal identities in official forms and census. Therefore, becoming Banjarese means becoming locals and Muslim in Kalimantan as well as loyal to Indonesia.

${ }^{16}$ Alfani Daud, Islam dan Masyarakat Banjar: Diskripsi dan Analisa Kebudayaan Banjar (Jakarta: PT Raja Grafindo Persada, 1997), 3.

${ }^{17}$ Mary Hawkins, 34.
The relations between people of Banjar and the Islamic religion has been very strong, and therefore according to Daud ${ }^{18}$ it can be said that people of Banjar are all Muslims. In practice, Islamic education traditions had successfully created Islamic scholars who have coloured the society in this community. Islamic education has been held in mosques, langgar (prayer buildings), and houses of 'ulema till now. Currently, formal Islamic education institutions flourish to provide more choices for this community to study Islam. Unsurprisingly, many kampong in South Kalimantan used to have double storey langgar to provide accommodation for wandering students to stay in the first floor and to pray and study with local 'ulema in the second floors. This strong tradition cannot be divorced from among others - the sultanate's supports on the spread of Islam in the kingdom. From here, it can be seen that politics and religion helped each other to achieve their respective objectives, and historical studies on this topic would be interesting to do.

On Banjarese migration to Tembilahan, Riau, as far as I am concerned, there is no single authentic book discussing about this, and therefore it has been extremely difficult to trace the history including why and how they were migrating from the Banjar sultanate at that time. Yet, unverified sources told us that after the Banjar war (1859-1905) between Banjarese and the Dutch colonialist, many Banjarese people could not accept the defeat and live under the colonialist authority whom they considered as kuffar or infidels. They then migrated voluntarily to places where they found comfort and peace even though this does not always mean free from the Dutch occupation because its influence had been spreading to all over Nusantara. Many of these Banjarese migrated to regions of Sumatera including Riau, Jambi and Bangka Belitung. Some of them reached and resided in Malaysia.

\footnotetext{
${ }^{18}$ Ibid., 5.
} 
One of areas where Banjarese migrated to is Tembilahan. Its natural conditions which are similar to those in South Kalimantan, i.e. lowlands and swamp areas made Tembilahan and Indragiri Hilir an ideal place for them to farm. In later decades, the migration continued to happen due to an additional attraction which is the charismatic Banjarese figure of Sheikh Abdurrahman Siddik al-Banjari or famously called "Tuan Guru Sapat" (TGS). He is one of the descendants of the famous and respected Sheikh Muhammad Arsyad al-Banjari who played an important role in Islamising the region of Banjar especially and Kalimantan generally in the early $19^{\text {th }}$ century. According Andin Ansyarullah Naim ${ }^{19}$, in his unverified accounts, some of the Banjarese migrants were those who came from the descendants of this respected Sheikh, and they brought along with them and continued this Islamic intellectual tradition in the migrated areas.

In turn, Banjarese people in a significant number - some estimated $70 \%$ of the whole populations in Tembilahan - have found this new place home and preserved their cultures and traditions. Up until now, Banjarese cultures in Tembilahan and the surroundings where Banjarese community was significantly present have remained strong. In these areas, a version of the Banjarese language is dominant. This is a quite older version of the language, which nowadays' Banjarese in South Kalimantan might find it difficult to fully understand. The Malay language derivation has been also strong in the Tembilahan's Banjarese. Apart from the use of the language, other performing arts like "Bamanda" and "Madihin" are still frequently practiced till now in the migrated areas.

\section{Becoming the Mufti of the Kingdom}

It is almost a convention that Banjarese peo-

\footnotetext{
${ }^{19}$ Andin Ansyarullah, Bunga Rampai Sejarah Jaringan Intelektual Diaspora Banjar, http://www.kompasiana.com/alfigenk/bungarampai-sejarah-jaringan-intelektual-diaspora-banjar_56233ca7e aafbde11315a27c. Internet: diakses pada 20 Juli $201 \overline{7}$.
}

ple relative to other ethnic groups like Malay and Bugisnese in the areas of Tembilahan were very dominant in religious roles and activities in society. This may not be unrooted from the influence of the respected Sheikh Abdurrahman Siddiq al-Banjari or "Tuan Guru Sapat" (TGS). As indicated previously, TGS is a descendant of Sheikh Muhammad Arsyad al-Banjari Martapura. TGS was born in Dalam Pagar Martapura in 1867 and died in Sapat Indragiri Hilir in 1939. After spending time studying Islam in his family circles in Martapura, he continued studying in Padang West Sumatra before traveling to Mecca for the same purpose ${ }^{20}$. In Mecca, he received knowledge from Sheikh Said Bakri Satta, Sheikh Ahmad Dimyati, Sheikh Ahmad Bafadil, dan Sheikh Umar Sambas. He also received from the popularly respected Nusantara's scholar in Mecca, i.e., Sheikh Nawawi al-Bantani ${ }^{21}$, yet in another narration, this sheikh was actually one of his colleagues in this holy place ${ }^{22}$. In Mecca, he took the opportunity to become a teacher in the Haram Mosque for several years before his return to Indonesia.

TGS, before studying in Mecca, resided in the Bangka Island with his parents as early Banjarese migrants in Sumatra. Therefore, on his return from Mecca, after several months in Martapura, he returned to Bangka and played an active role in educating and changing people's way of life to become more compliant to Islamic teachings. He corrected many deviating practices of the religion. After spending 15 years in Bangka, on the invitation of a friend named H. Arsyad, a Banjarese from Indragiri, he moved to Indragiri in a kampong of Sapat. Here, he cleared land in Parit Hidayat which was at that time considered as a haunted place where people worship

\footnotetext{
${ }^{20}$ Abdul Muthalib, Tuan Guru Sapat: Kiprah dan Perannya dalam Pendidikan Islam di Indragiri Hilir Pada Abad ke 20 (Yogyakarta: EJA Publisher, 2014), 17.

${ }^{21}$ Abdul Hamid. Pemikiran Syekh Abdurrahman Siddiq alBanjari tentang Pendidikan Akhlak dan Tasawwuf (Bengkulu: LP2 STAIN Curup, 2013), 10.

${ }^{22}$ Ibid., 25.
} 
spirits. He taught how to become good Muslims who can tolerate differences. According to Muthalib $^{23}$, at that time there were two groups of community who almost attacked each other because of misunderstanding about issues of Islamic jurisprudence. TGS acted as an authoritative mediator who explained in detailed and convincing way about the debated issues so that the groups accepted and stopped the frictions. In Sapat, he also established a pesantren, mosque and dormitories for students to stay. This is the first pesantren in Indragiri, and the students came from different regions including Malaysia and Singapore.

The roles of TGS in social transformation in society were undeniable, and the outcomes were felt by many. Not only did he work in the field of Islamic missionary, but was also able to exert an example of how to clear the land and farm which nobody took the initiative before. By so doing, he contributed significantly to the economic development of society. In academic, he was a prolific writer producing 23 works in the forms of books, and notes in various disciplines. This showed his capacity as a religious intellectual who possessed various knowledge. Therefore, he was approached to become the mufti of the Indragiri Sultanate. He accepted this invitation with two conditions, i.e. not receiving salary and remaining to stay in Sapat ${ }^{24}$. At that time, the capital of the Sultanate was located in Rengat. The condition of not receiving salary indicates his understanding of the importance of independence for him in doing da'wah. He believed that 'ulema can be co-optated by the authority and lost their independence when they received materials and facilities from the authority. Amateurism ${ }^{25}$ as the opposite of professionalism which requires salary for works that have been done was an inseparable attitude from his personality. In this way, they had freedom and

\footnotetext{
${ }^{23}$ Ibid., 65 .

${ }^{24} \mathrm{Ibid}$.

${ }^{25}$ Edward Said, 57.
}

independence in issuing Islamic verdicts without any fear of loss.

\section{Maintaining Domination}

Since the era of TGS, the position of Banjarese 'ulema has been well regarded. After TGS, a number of Banjarese names who continued his roles include among others Tuan Guru Abdul Hamid Sulaiman, Tuan Guru Nasri and Tuan Guru Abdul Muis. They became important references for the community of Tembilahan. A Bugisnese academic, Zainal Ilmi, acknowledged the continuing domination by Banjarese 'ulema in the field of religion. He said that local community has strongly had faith in them and the depth of their Islamic knowledge. He says, "in various religious ceremonies, community here always invites Banjarese "ulema because they are good in both Islamic knowledge and rhetoric".

Besides exercising influence through non-formal religious preaching, some of Banjarese "ulema have established Islamic schools and pesantren in Tembilahan. Tuan Guru Abdul Muis, for example, was known as the kiai in his pesantren and the leader of a Sufism order which have made him a famous and influential figure. Establishing pesantren or Islamic schools seems to be the tradition introduced by TGS decades ago.

M. Bahri, one of the informants, describes that Banjarese 'ulema are often asked by government in providing advices in religious matters. In some cases, 'ulema from Banjar were appointed to sit as chairpersons of Majlis Ulama Indonesia (Indonesian 'Ulema Council: MUI) at the levels of province and district such as TG Abdul Hamid Sulaiman and Prof. Dr. Mahdini, M.A. It is acknowledged, however, whether the advices were taken into consideration or not depends on the government's interests. M. Bahri further explains that even the position of the MUI's chairperson is highly dependent on the relations between the contending 'ulema and government. In the context of Indragiri Hilir, as 
suggested by an informant, a regent could intervene the election of MUI's chairperson to elect someone he liked while many 'ulema viewed that the candidate was not qualified for such a highly regarded religious position.

The role of Banjarese 'ulema in social transformation in Tembilahan, as another informant Abdul Halim argues, was played more in education and preserving religious values in society. Even in this field, however, none of current 'ulema was comparable to TGS. Abdul Halim explains:

I haven't seen any figure nowadays that can be compared to TGS in both Islamic knowledgeability and role played in society. This may be because the current "ulema do not go to Mecca to study. Also, TGS was indeed very concerned with societal development as told by our parents. The books he authored are highly oriented to resolve social problems at that time.

'Ulema's sensitivity towards social problems sounded to be important for all the informants in evaluating 'ulema's credibility. M. Bahri assesses that many 'ulema nowadays are afraid of the community's hostility in delivering religious messages so that social problems have been more both growing in numbers and complicated to solve. He points to some examples of these problems in Tembilahan including prostitutes, gambling, drug uses and so forth. "What they have done is only to say lightly about these problems in their speeches", says M. Bahri. He then continues to tell that when he was the MUI's chairperson he was actively involved in eradicating "togel" gambling. He and his family received terrors and threats from people. At that time, as Yazid another informant says, the majority of people in Tembilahan was participating in this type of gambling. M. Bahri's role as a religious figure at that time was acknowledged successful in eradicating gambling practices with the cooperation with government and police.

\section{Against Politicians' Temptation}

Political temptation in the forms of becoming politician or helping politicians to achieve their goals is, according to the informants, a real challenge to the 'ulema's credibility. The fact that many 'ulema come from the majority Banjarese background in Tembilahan has led politicians from other ethnic backgrounds to persuade them to be on their side. These 'ulema possess a wide access and strong influence on community, something that is probably absent from many politicians. In fact, there are some Banjarese 'ulema who stay close to, or are pulled by, politicians to help them achieve political goals. Azizi explains, "Indeed, some of our 'ulema get along with certain politicians. This is something not right as society sees it negative". Informants seem to always relate the closeness of "ulema with politicians to worldly interests.

All informants argue that what TGS had done in dealing with the authority at that time cannot be considered efforts to become closer to the sultan for his own interests, but the relationship started from the sultan and TGS accepted for the benefits of people.

Azizi: "It is true that TGS became the mufti at that time. But, it was not his own desire, and he rejected salary given by the sultan to maintain his integrity".

Also, M. Bahri defends TGS's position: "TGS was able to maintain his independence in delivering the truth to his people. He was not at all influenced by the sultan, but he exerted influence. In people's eyes, TGS's position was much more respected by community at that time".

In short, there are Banjarese 'ulema who become politicians or support politicians in Tembilahan, and this has created particular impression and judgement by society. But, the majority remain independent from politicians' co-optation. In informants' eyes, 'ulema who have regular income from employment are usually much more independent from politicians. They have integrity and credibility as 'ulema. They are 
those whom the community places their hopes to guard religious morality and values and, hence, contribute to the process of social transformation.

\section{Charisma, Independence and Politics of Ethnicity}

Another factor that undermines 'ulema's independence, according to the informants, is because they do not have or have lost charisma. Most informants define charisma as respect by community members received by 'ulema. This definition is not entirely incorrect because respect in fact originates from followers due to charisma possessed by the figure. Oxford Dictionary as cited in Wikipedia provides a clearer definition, i.e. (1) compelling attractiveness or charm that can inspire devotion in others, (2) a divinely conferred power or talent ${ }^{26}$. So, charisma is actually a given quality that inspires others to love, obey, and be loyal to those who possess it. In some cases, it is divinely given, but in other cases, it is developed through times following extra-ordinary efforts in building spirituality. Therefore, Abdul Halim argues that charisma owned by Banjarese 'ulema in the past was generated from the depth of Islamic knowledge, persistency in faith and piety, independence from authority. In current cases, as the informants believe, besides knowledgeability and piety which are not comparable to those of previous 'ulema like TGS, the involvement of the current 'ulema in politics which is often driven by worldly interests has undermined their charisma.

Abdul Halim and Azizi agree that incomparable knowledgeability of the past 'ulema was enhanced through challenging learning processes. They showcase TGS as an ideal example of a hardworking student in Mecca, had become a distinguished teacher in Mecca, and joined a Sufism order to improve spirituality.In contrast, most of the current Banjarese 'ulema in Tembi-

${ }^{26}$ Wikipedia. Charisma. https://en.wikipedia.org/wiki/Charisma. Internet: diakses pada 16 Juli 2017. lahan graduated from local pesantren or to the farthest from pesantren in Java or South Kalimantan and do not have spirituality. One 'alim obtaining Lisence (Lc.) from Egypt has therefore become a hope for Banjarese community in Tembilahan, but he still needs time to prove his developed spirituality and knowledge.

According to informants, charisma generates from the ability of 'ulema to become independent from worldly interests such as wealth and political position (sense of exile) which will establish their integrity. Abdul Halim, confirmed by all informants, says: "Here in Tembilahan, if an 'alim always gets along with a politician or government, he will not receive respect from community". Samri adds, "This is good [as] there is control by community. So 'ulema will act very carefully". Many informants point out to local elections when Banjarese 'ulema whose access and influence in the deep side of the community are strong became targets by politicians to use them in their campaigns. As the informants say, there were 'ulema who sacrificed independence and integrity for worldly positions. They rejected these "ulema justification which is to strengthen their da'wa by partnering with government or politicians because the seen phenomena indicate otherwise.

Since the reform era in 1998 where political decentralisation began to be implemented, ethnic identity and sprit have become thickening. In both the Riau province and the Indragiri Hilir Regency, this has become a hot issue where the term "sons of soils" (putra daerah) forms a very vital identity for people who aspire to contend in political elections. In the Indragiri Hilir Regency, as acknowledged by the informants, the ethnic polarisation to some extent exists among Banjarese, Malays and Bugisnese. However, the cooperation among ethnic groups has gone very well and harmonious interactions are not a utopia. In history in this area, there are local leaders who were ethnically partisans, and others who uphold the principles of equality among 
groups. In this context, Banjarese 'ulema as informal community representatives usually play very carefully. With the exception of a couple of 'ulema, their supports are usually directed to those politicians who are inclined to facilitate religious development in society.

\section{Conclusion}

This preliminary research found that the role of Banjarese "ulema in Tembilahan and its surroundings has been very big in educating and developing Muslim community. They played this role dynamically following changes occurring in this context. They change society through Islamic education which can shift the community's way of thinking and life, and in turn bring about massive social changes. As an example, religiosity demonstrated by Tembilahan community cannot be separated from the Banjarese 'ulema's role in educating these people. Their role has shifted from social oriented to more educational in order to maintain religious teachings and values in both personal and community levels.

Each era has its challenges. TGS in his time demonstrated ability to play roles as an educator, motivator, and reformer in society in both social and religious spheres. The challenges at that time encompassed community's lack of knowledge and faith contaminated with "takhayul" and "khurafat". His intervention successfully changed Indragiri's community to become religiously educated and socio-economically better. Nowadays, Banjarese 'ulema in Tembilahan remain active as educators and preachers to improve the conditions of community. Yet, challenges in social changes mediated by the use of information, technology and communication may have impacted community members in both positive and negative ways. The social norms breaching has also been various. Therefore, the tasks of 'ulema become more complicated because they have to be always vigilant with updated knowledge, skills and insights. On another side, political conditions in Indonesia has increasingly opened room for 'ulema to take share either as an active player or as an active supporter. This improvement may drag 'ulema into situations where they may sacrifice their integrity, independence, and credibility. Consequently, they fail to develop in themselves sense of exile, speaking truth to power, and amateurism which in turn will loss charisma and respect from society. At this point, their role in social transformation may fade.

This research needs to be continued with deepen exploration about this topic which covers also legacy of the "ulema in forms of works and institutions they might have produced. Studies about their teachings through this legacywill be able to describe their roles further in transforming Tembilahan's society. It would also be more interesting to investigate about the dynamic relations between 'ulema and government in framing their roles in social transformation. These studies are important to see more closely the roles of Banjarese "ulema in this contemporary era.

\section{References}

Alatas, Syed Hussain. Intellectuals in Developing Societies. London: Frank Cass, 1977.

Ansyarullah, Andin. Bunga Rampai Sejarah Jaringan Intelektual Diaspora Banjar. http:// www.kompasiana.com/alfigenk/bunga-rampai-sejarah-jaringan-intelektual-diaspora-banjar_56233ca7eaafbde11315a27c. Internet: diakses pada 20 Juli 2017.

Bourdieu, Pierre \& Passeron, Jean-Claude. Reproduction in Education, Society and Culture. 2nd ed. London: Sage, 1990.

Creswell, John W. Research Design: Qualitative, Quantitative, and Mixed Methods Approaches. Los Angeles: SAGE Publications. 2009. 
Daud, Alfani. Islam dan Masyarakat Banjar: Diskripsi dan Analisa Kebudayaan Banjar. Jakarta: PT Raja Grafindo Persada, 1997.

Desjardins, Richard. "Education and Social Transformation." European Journal of Educatio 50, no. 3 (2015): 239-244. Doi: 10.1111/ejed.12140.

Gramsci, Antonio. Prison Notebooks -- the Intellectuals: the Formation of the Intellectuals. In Roger S Gottlieb (Ed.), An Anthology of Western Marxism (pp. 113-120). New York: Oxford University Press, 1989.

Hamid, Abdul. Pemikiran Syekh Abdurrahman Siddiq al-Banjari tentang Pendidikan Akhlak dan Tasawwuf. Bengkulu: LP2 STAIN Curup, 2013.

Hawkins, Mary. "Becoming Banjar." Asia Pacific Journal of Anthropology 1, no, 1 (2000): 24-36. Doi: 10.1080/144422100100017 05830 .

Hilmy, Masdar. "Agama dan Politik." Kompas (16 July 2014).

Horikoshi, Hiroko. A Traditional Leader in A Time of Change: The Kijaji and Ulamain
West Java (Ph.D Unpublished). The University of Illinois, Urbana-Champaign, 1976.

Lincoln, Yvonna S. and Guba, Egon G. Naturalistic Inquiry. Newbury Park: Sage Publications. 1985.

Miles, Matthew B. and Huberman, A. Michael. Qualitative Data Analysis. Thousands Oaks: SAGE Publications. 1994.

Muthalib, Abdul. Tuan Guru Sapat: Kiprah dan Perannya dalam Pendidikan Islam di Indragiri Hilir Pada Abad ke 20. Yogyakarta: EJA Publisher, 2014.

Said, Edward. Representations of the Intellectuals. London: Vintage, 1994.

Taib, Mohammad Imron Mohammad. Who is an Intellectual. 2017. http://www.thereadinggroup.sg/Articles/Who\%20is $\% 20$ an\%20Intellectual.pdf.

Turmudi, Endang. "Religion and Politics: A Study on Political Attitudes of Devout Muslims and the Role of the Kyai in Contemporary Java." Southeast Asian Journal of Social Science 23, no. 2 (1995): 18-41.

Wikipedia. Charisma. https://en.wikipedia.org/ wiki/Charisma. Internet: diakses pada 16 Juli 2017. 